Dantas Filho, J.B.P., Barros Neto, J.P., Mourão, A., Rocha, A.B.,Luccas, A. V., Saggin, A. (2018). "Respect for people's well-being: meditation for construction workers" In: Proc. $26^{\text {th }}$ Annual Conference of the International. Group for Lean Construction (IGLC), González, V.A. (ed.), Chennai, India, pp. 11601169. DOI: doi.org/10.24928/2018/0256. Available at: www.iglc.net

\title{
RESPECT FOR PEOPLE'S WELL-BEING: MEDITATION FOR CONSTRUCTION WORKERS
}

\author{
João Bosco Pinheiro Dantas Filho ${ }^{1}$, José de Paula Barros Neto², AlexandreMourão ${ }^{3}$, \\ Andréa Benício da Rocha ${ }^{4}$, Andre VieiraLuccas, and Angela Saggin 6
}

\begin{abstract}
Stressful environments are often found in construction industry which makes important to study the relation between stress and work. Alcohol or illicit drugs were reported to be common short-term alternatives to reduce anxiety in male-dominated industries and have long-term implications for health and well-being. "What countermeasures can be used by construction workers?" A set of emotion-focused coping strategies is identified, such as physical exercise, recreational activities and meditation.

According to the Brazilian Ministry of Health, meditation is an instrument of physical, emotional, mental, social and cognitive strengthening that promotes concentration, stimulates well-being, relaxation, reduces stress, hyperactivity and depressive symptoms. "But would construction workers be willing to meditate?" The purpose of this paper is to assess the initial perceptions of construction workers under meditation training.

This research has a qualitative approach and its strategy is a unique case study. Four meditation sessions were applied at the construction site during lunch break. Multiple sources of evidence were used: interviews and videos. The data analysis was qualitative. The results indicate: (1) construction workers consider that meditation values them and (2) they also recommend its implementation. This research gives some information that there is viability for meditation in construction.
\end{abstract}

\section{KEYWORDS}

Lean Construction, Safety, meditation, workers' health, well-being.

Architect, Federal Institute of Education, Science and Technology of Ceará, Researcher of GERCON, Federal University of Ceará, Fortaleza, Brazil, arquibosco@gmail.com

2 Full Professor, Department of Structural Engineering and Civil Construction, Leader of the GERCON, Federal University of Ceará, Fortaleza, Brazil, barrosneto@gercon.ufc.br

3 Civil Engineer, Technical Director of C. RolimEngenharia Ltda., Brazil, alexandre@crolim.com.br

4 Yoga and meditationinstructor, Ayurveda therapist, Espaço Tenda, Fortaleza, Brazil,dea_benicio@hotmail.com

5 Civil Engineer, Researcher of GERCON, Fortaleza, Brazil,andreluccas90@ gmail.com

6 Civil Engineer, Lean \& Green Coordinator of C. RolimEngenharia Ltda., Brazil, angela@crolim.com.br 


\section{INTRODUCTION}

Thirty per cent of lost productivity worldwide is caused by psychiatric conditions such as depression, anxiety and schizophrenia - all of which are exacerbated by chronic stress(Nestler 2012).Work stress is recognised world-wide as a major challenge to workers' health and the healthiness of their organizations(Leka et al. 2004).Work-related stress in developing countries is often made worse by a broad spectrum off actors outside the work environment from gender inequalities, poor paths of participation and poor environmental management of industrial pollution to illiteracy, parasitic and infectious diseases, poor hygiene and sanitation, poor nutrition, poor living conditions, inadequate transportation systems and general poverty(Houtman et al. 2007).Stressors can be onetime and acute, such as unexpected job transfer or job loss, or more chronic, such as bad bosses, broken peer relationships, and dysfunctional team members(Tabibnia and Radecki 2018).Scientific evidence demonstrates that construction personnel, including both professionals and manual workers, experience various types of stressors(Leung et al. 2015).

Under stress, the body ramps up its production of certain hormones, such as cortisol, and other biochemical factors to mediate an appropriate response to short-term stress, but when overproduced for months or years, they can alter gene expression, probably with deleterious effects(Blackburn and Epel 2012).

There are two particular coping styles in response to managing a stressful situation: problem-focused coping and emotion-focused coping(Langdon and Sawang 2017).The practice of meditation appears to be beneficial in environments where people have high levels of stress, such as the workplace (Cramer et al. 2016; Elder 2014). During meditation, our experiences are not intentionally confronted, but only observed, and its practice turns into learning how not to be negatively influenced by understanding facts as mere mind flows (Teasdale 1999). The cognitive psychotherapy assumptions state the interpretation of facts is more relevant than the facts themselves(Menezes et al. 2011).

The aim of the study was to understand the perceptions of construction workers who had participation of a meditation-training program as emotion-focused coping. The objectives were to discover if they would be willing to practice meditation, and its preparation stretching, respiratory exercise and relaxation.

\section{BACKGROUND}

\section{MEDITATION}

Meditation is a wide term and gathers several techniques that help focus attention in a non-analytical way, avoiding discursive, persistent and obsessive thoughts (SHAPIRO, 1980, quoted by, KRYGIER et al., 2013). Among different meditation practices, there is the so-called full attention, which consists of paying attention to the present moment with no judgements of the experiences (KABAT-ZINN, 1990, quoted by HOLZEL et al., 2011).

Meditation practice and improvement in psychological symptoms and perceived stress, suggest that the improvements result from regular practice and are related to the 
significant reductions in psychological distress and perceived stress (Carmody and Baer 2008).

The role of emotion regulation in meditation is demonstrated by the alteration of emotional responses in terms of the overcoming of sorrow and distress as part of meditation practice (Holzel et al. 2011).

The psychological and organizational literature suggests that full attention meditation can have a meaningful influence in the well-being of the employees (Good et al. 2016). Figure 1 summarizes the flow of full attention influence mechanism in the work environment results.

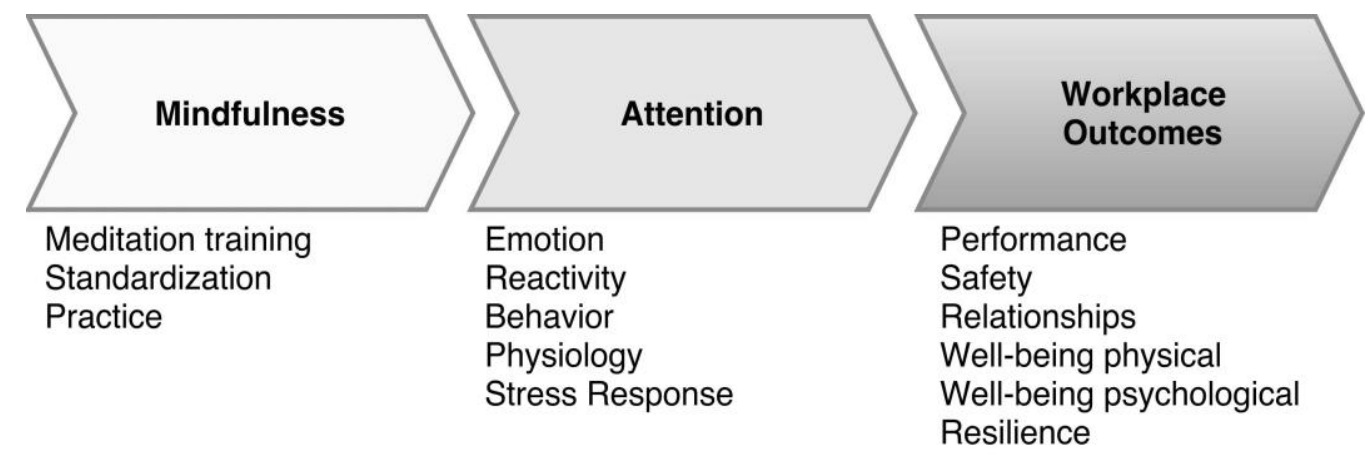

Figure 1: Chart that relates full attention to the workplace results. Elaborated by the author and adapted from Good et al. (2016).

Meditation is also new for those who search for an effective and economic strategy to face stress (Choe et al. 2014). Leisure activities can help people to forget or stay away from life stressful events and keep mind busy for a short period of time, whereas meditation offers long-term effects towards emotion control, physiological benefits, development of emotional intelligence and compassionate emotions (Choe et al. 2014).

\section{CONSTRUCTION WORKERS' WELL-BEING}

Researches show that some life habits, such as smoking, alcoholism and other drugs, increased their occurrence after some employees started to work with construction (Haupt et al. 2016).Along with physical inactivity and inadequate food habits, smoking is the main risk factor for chronic non-communicable diseases, which kill the most in Brazil and around the world (Duncan et al. 2012).

Studies indicate that the mechanisms to face stressful events, adopted by construction workers, lead to worse feelings of psychological suffering (Langdon and Sawang 2017).

Wellbeing is a new concept that was introduced to expand the social pillar of sustainability (Vasconcelos et al. 2015).

Table 1 summarizes five types of stressors that construction personnel experience. 
Table 1: Types of stressors(Leung et al. 2015).

\begin{tabular}{|c|c|c|}
\hline & Type stressor & Numbers on Faces \\
\hline 1 & Personal & Type A behaviour and work-home conflict \\
\hline 2 & Interpersonal & poor interpersonal relationship \\
\hline 3 & Task & $\begin{array}{c}\text { work overload, role ambiguity, role conflict, effort-reward imbalance } \\
\text { and lack of feedback from superior }\end{array}$ \\
\hline 4 & Organizational & lack of manpower support \\
\hline 5 & Physical & poor office environment and unsafe site environment \\
\hline
\end{tabular}

\section{RESPECT FOR PEOPLE}

The organizations that show respect for their workforce and discuss their questions tend to have less problems, either when they recruit or when they keep their top-quality employees. Besides, workers who feel valued and respected are more likely to increase the opportunity of identifying themselves with and add value to the team and the organization (Thomas and Thomas 2008).

Figure 1 shows how people understand the respect concept as a key to successful partnerships and teamwork integration, which are also viable through team members' personal relationships.

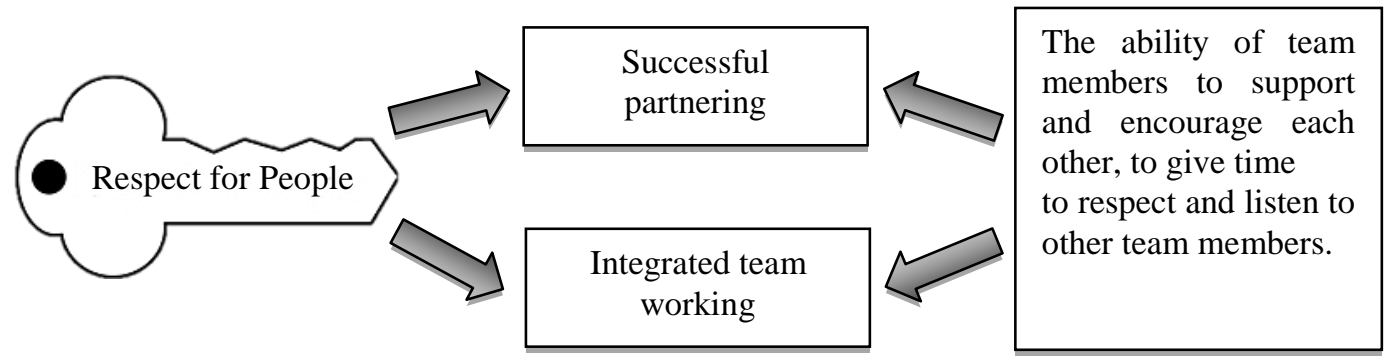

Figure 1: Diagram of concept association and dependence elaborated by the author and adapted from Thomas and Thomas 2008.

Lean value streams must be developed with respect for people(Rother and Shook 2003).The results of respect for people will be beneficial to all, because in showing respect for the workforce, it earns both the respect of the workforce and the public in general(Movement for Innovation 2000).

\section{METHOD}

\section{APPROACH}

This research has a structuralist epistemological paradigm (Gomides 2002). Considering the nature of the data, this study is qualitative (Vasconcelos and Arcoverde 2007).

Qualitative method was used, because the meaning of meditation for the lives of people in real conditions, and the focus is on the participants' perception. For contribute 
with insights about emerging concepts that can help explain human social behaviour, multiple evidence sources were used, according to Yin (2011).

\section{RESEARCH STRATEGY}

The action research method is adopted as a strategy, because the empirical basis is conceived in close relation to action or solution of a group problem, in which researchers and participants are involved collaboratively (Gil 2008). The action research method approaches scientific research from an interventionist's viewpoint, and researchers both observe and participate in the phenomena under study(Baskerville 1997).

Qualitative data-collection techniques were combined, including interviews, direct observation and filming, in order to understand a contemporary phenomenon (Yin 2001).As the meditation training intervention went by, information collection happened with camera recording participants for later analysis of filming.

The study design is made of three stages. The first one was about the literature review, searching for the main concepts that guided this paper: "respect for people", "well-being" and "meditation". The second stage was about applying Action Research method, when the construction workers went under meditation training. A corporate meditation program was developed and took four weeks long. Guided Meditation technique was applied and included: Preparation with Stretching, Respiratory Exercise and Relaxation. Through the progressive relaxation, students arrive at a relaxed mental state in which their distractions are reduced and their imagination can flow more freely(Marques et al. 2014).Guided meditation first uses the vocalization of the body's topography for relaxation of the body, then we induce the observation of external stimuli, sounds and sensations to go as far as mind observation and mental relaxation, then induce a specific internal focus for concentration that can be in the sensation of breathing.

On the third stage, there were discussion and analysis of the experiences to build the research final report.

The analysis unit is the workers' well-being of a Lean Construction-Based company. The informants are the teamwork members, as well as coordinators and managers, a total of eight respondents. The analysis of the problem was based on a qualitative approach through the Research-Action-Participant. Thus, we did not use sample logic commonly used in quantitative research. This work followed the logic of replication (Yin 2001, 2013): construction workers were invited and participated in the research-actionparticipant voluntarily in order to demonstrate results, without pretensions of generalization. The research point of view is that of construction workers.

\section{THE COMPANY}

The case study was carried out at C. Rolim Engenharia, a company located in Fortaleza, Ceará, Brazil, founded in 1977 and with a 14-year lean working day. The choice of the company was guided by the information, to maximize the usefulness of the qualitative information that would be provided to the research objectives (Takahashi 2013). The choice of company is justified by its management model, highlighting practices that have Lean, Life, Green and BIM elements. Lean as a central idea and the main concerns; the human capital represented by Life; the environment identified as Green; and the search 
for innovation and information technology and communication applied to the construction process represented by BIM.A construction company that develops social practices (such as giving away school kits to the workers' families and birth kits to the workers' newborn children)

\section{RESULTS}

Figure 3 brings the socio characterization of the research participants. Out of the 8 participants, 75\% were married, 37.5\% were bricklayer's mate, $25 \%$ finished High School. The participants' level of education and age were also observed.

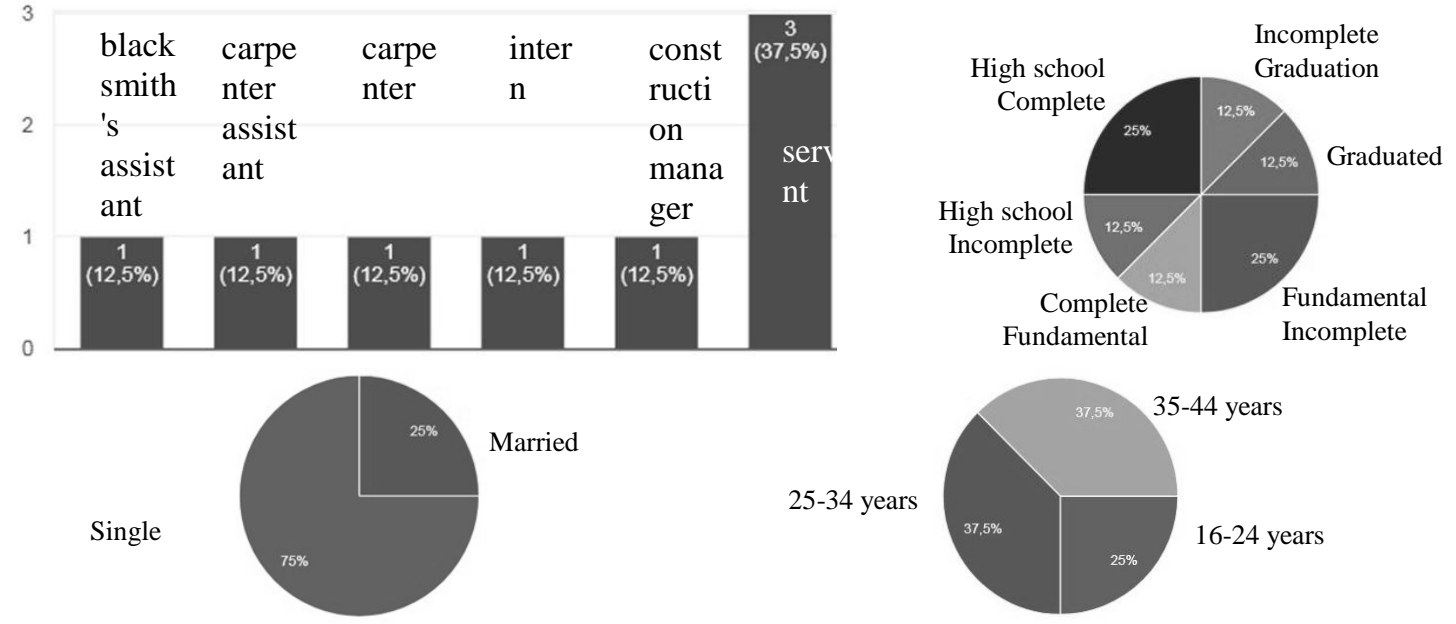

Figure 2: Distribution of socio variables, work position, marital status, education, age.

Figure 4 shows construction workers practicing conscious breathing and relaxation techniques. Based on analysis of filming realized it was possible to observe that construction workers did not have great difficulties to put in to carry out the practice. It was observed that all participants followed teacher's instructions with seriousness and attention and performed the exercises of conscious breathing and relaxation, which had purpose of preparing for meditation moment.
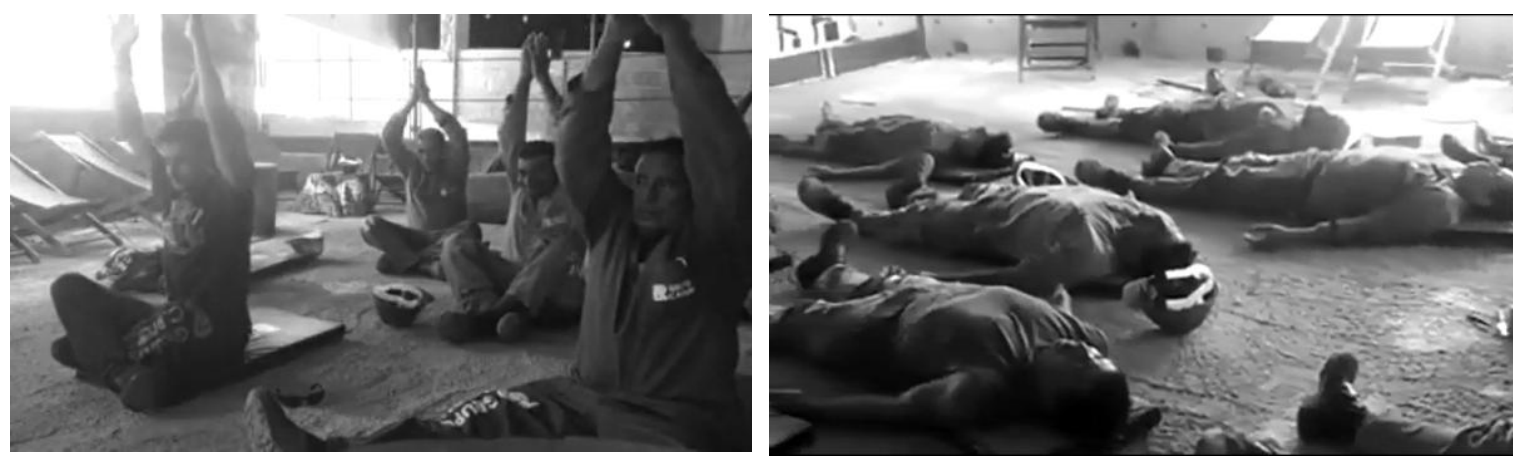

Figure 3: Shots of conscious breathing and relaxation techniques in the job site 
It was observed that construction company provided a space for well-being at construction site, equipped with chairs and sun beds contributed positively to realization of meditation training. Figure 5 demonstrates construction workers during meditation practice that occurred in the lunch break with the use of music as a focusing tool. The day of the week in which the meditation training was applied was planned to not coincide with the scheduling days of machined concrete. In this way, noises produced by the pumping of concrete were avoided, which would make the practice of meditation unfeasible.

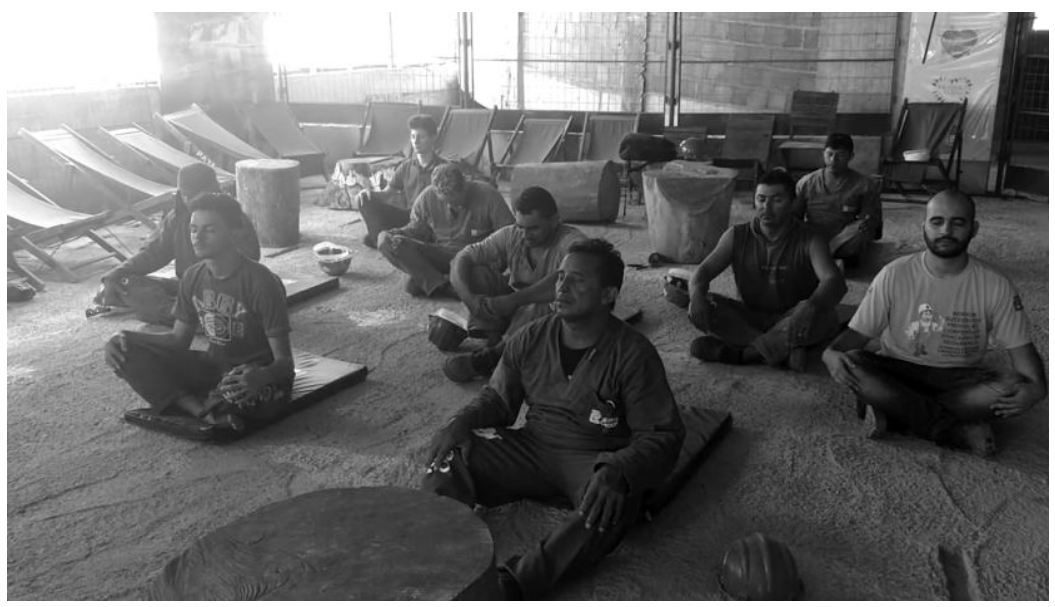

Figure 1: Shots of meditationin the job site

The analysis of the data collected through interviews indicated that majority of the interviewees that practiced meditation in the job site totally agreed there are demands to implement this activity in the job site. Interviewees agreed there are barriers to put the activity into practice. About the usefulness of meditation in construction, majority of the interviewees fully agreed in favor of meditation. Majority of the participants would recommend meditation to their colleagues, including the ones who work for other companies. Interviewees analyzed positively meditation practice in construction. Majority of interviewees agreed meditation in construction values the workers, contributing more for good attitudes that intend to offer higher satisfaction levels to the workers of the approached company.

The barriers against meditation could be overcome with good planning along time, in a way it does not mess the employees' work routine and their work pace. For example, workers would receive well the idea of practicing meditation early in the morning. Most of them arrive early, which is a positive aspect. Practicing meditation at lunch time or at the end of the workday would interfere in their resting time and delay their home arrival. This data was positive, considering that the ones who participated on the first day invited other workers to come for the next sessions. One of the interviewees said that, after the first day of practice, he tried to teach his family what he had learned from the training in the job site. 


\section{CONCLUSIONS}

First, this research shows there is viability for meditation in construction. The results indicate: (1) participants construction workers consider that meditation values them and (2) they also recommend its implementation.

The study also shows it is viable to introduce a meditation routine, as a emotionfocused coping, within the weekly activities at a construction site.

The main contribution of this paper is to offer, in the construction industry context, an opportunity to express respect for the workforce and obtain benefits out of this important principle. It is believed that, through these actions, the company is "building" people before "building" houses. By the way, these actions are evidences for one of the Toyota Production System Principles: Respect for People.

Finally, this research was limited due the short period of time available for practicing the meditation routine at the construction site. Thus, the analysis was qualitative, exploring the expected impacts and results for the workers wellbeing. The research findings provide important insights on how the construction industry could improve the quality of life of it is most important resource: people.

\section{ACKNOWLEDGMENTS}

Authors would like to thank C. Rolim Engenharia Ltd. for allowing the results of this study to be published. The authors would like to thank those who contributed to the collection and validation of Case Study data for the purposes of this research. Also, they would like to thank those participants who are striving to applying the corporate meditation program. We are grateful for your data and valuable insights into future research.

\section{REFERENCES}

Baskerville, R. L. (1997). "Distinguishing action research from participative case studies." Journal of Systems and Information Technology, 1(1), 24-43.

Blackburn, E. H., and Epel, E. S. (2012). "Too toxic to ignore." Nature, JOUR, Nature Publishing Group, a division of Macmillan Publishers Limited. All Rights Reserved., 490, 169.

Carmody, J., and Baer, R. A. (2008). "Relationships between mindfulness practice and levels of mindfulness, medical and psychological symptoms and well-being in a mindfulness-based stress reduction program." Journal of Behavioral Medicine, 31(1), 23-33.

Choe, J., Chick, G., and O'Regan, M. (2014). "Meditation as a kind of leisure: the similarities and differences in the United States." Leisure Studies, 0(0), 1-18.

Cramer, H., Hall, H., Leach, M., Frawley, J., Zhang, Y., Leung, B., Adams, J., and Lauche, R. (2016). "Prevalence, patterns, and predictors of meditation use among US adults: A nationally representative survey." Scientific Reports, Nature Publishing Group, 6(October), 1-9.

Duncan, B. B., Chor, D., Aquino, E. M. L., Bensenor, I. M., Mill, J. G., Schmidt, M. I., Lotufo, P. A., Vigo, Á., and Barreto, S. M. (2012). "Doenças Crônicas Não 
João Bosco Pinheiro Dantas Filho, José de Paula Barros Neto, AlexandreMourão, Andréa

Benício da Rocha, Andre VieiraLuccas and Angela Saggin

Transmissíveis no Brasil: Prioridade para enfrentament e investigação.” Revista de Saude Publica, 46(SUPPL.1), 126-134.

Elder, C. (2014). "Effect of Transcendental Meditation on Employee Stress, Depression, and Burnout: A Randomized Controlled Study." The Permanente Journal, 18(1), $19-23$.

Gil, A. C. (2008). Métodos e técnicas de pesquisa social. JOUR, Atlas, São Paulo.

Gomides, J. E. (2002). "a Definição Do Problema De Pesquisa a Chave Para O Sucesso Do Projeto De Pesquisa." Revista do Centro de Ensino Superior de Catalão, Ano IV(6), 11.

Good, D. J., Lyddy, C. J., Glomb, T. M., Bono, J. E., Brown, K. W., Duffy, M. K., Baer, R. A., Brewer, J. A., Lazar, S. W., Spence, G. B., Good, D. J., Lyddy, C. J., Glomb, T. M., Bono, J. E., Brown, K. W., Duffy, M. K., Baer, R. A., Brewer, J. A., and Lazar, S. W. (2016). "Contemplating mindfulness at work: an integrative review." Journal of Management, JOUR, SAGE Publications Sage CA: Los Angeles, CA, 42(1), 114-142.

Haupt, T. C., Smallwood, J., Kalindindi, S., and Kalindindi, S. (2016). "The Health and Wellbeing of Indian Construction Workers: A Comparison between Older and Younger Workers." 18th CIB World Building Congress, Salford, 67-79.

Holzel, B. K., Lazar, S. W., Gard, T., Schuman-Olivier, Z., Vago, D. R., and Ott, U. (2011). "How Does Mindfulness Meditation Work? Proposing Mechanisms of Action From a Conceptual and Neural Perspective." Perspectives on Psychological Science, 6(August), 537-559.

Houtman, I., Jettinghoff, K., and Cedillo, L. (2007). "Raising awareness of stress at work in developing countries." Protecting workers' health series, (6), 1-51.

Krygier, J. R., Heathers, J. A. J., Shahrestani, S., Abbott, M., Gross, J. J., and Kemp, A. H. (2013). "Mindfulness meditation, well-being, and heart rate variability: A preliminary investigation into the impact of intensive vipassana meditation." International Journal of Psychophysiology, Elsevier B.V., 89(3), 305-313.

Langdon, R. R., and Sawang, S. (2017). "Construction Workers' Well-Being: What Leads to Depression, Anxiety, and Stress?" Journal of Construction Engineering and Management, 144(2), 4017100.

Leka, S., Griffiths, A., and Cox, T. (2004). Work Organization and stress : systematic problem approaches for employers, managers and trade union representatives. Journal of vocational behavior, World Health Organization, Nottingham.

Leung, M., Chan, I. Y. S., and Cooper, C. L. (2015). "Sources of stress affecting construction personnel." Stress Management in the Construction Industry, JOUR, Wiley Online Library, 91-148.

Marques, J., Dhiman, S. K., and Biberman, J. (2014). "Teaching the un-teachable: storytelling and meditation in workplace spirituality courses." Journal of Management Development, 33(3), 196-217.

Menezes, C. B., Dell'Aglio, D. D., and Bizarro, L. (2011). "Meditação, bem-estar e ciência psicológica: revisão de estudos empíricos." Interação psicol, 15(2), 239-248.

Movement for Innovation. (2000). A Commitment to People:" Our Biggest Asset. Movement for Innovation. 
Nestler, E. J. (2012). "Stress makes its molecular mark." Nature, JOUR, Nature Publishing Group, a division of Macmillan Publishers Limited. All Rights Reserved., 490, 171.

Rother, M., and Shook, J. (2003). "Learning to See Value Stream Mapping to Create Value and Eliminate Muda." Lean Enterprise Institute Brookline, 102.

Tabibnia, G., and Radecki, D. (2018). "Resilience training that can change the brain." Consulting Psychology Journal, 70(1), 59-88.

Takahashi, A. R. W. (2013). Pesquisa Qualitativa Em Administração -Fundamentos, Métodos e Usos no Brasil. ATLAS, São Paulo.

Teasdale, J. D. (1999). "Metacognition, mindfulness and the modification of mood disorders." Clinical Psychology \& Psychotherapy, JOUR, Wiley Online Library, 6(2), 146-155.

Thomas, G., and Thomas, M. (2008). Construction partnering and integrated teamworking. BOOK, Blackwell Publishing Ltd, Oxford.

Vasconcelos, A. L. F. de S., and Arcoverde, A. C. B. (2007). "O Rigor Científico em Pesquisa, quanto á Fidelidade e à Validade dos Resultados Obtidos: Uma Experiência da Utilização da Técnica Qualitativa na Prática Avaliativa." Revista Eletrônica de Ciência Administrativa-RECADM, JOUR, 6(2), 1-16.

Vasconcelos, I. A. de, Cândido, L. F., Heineck, L. F. M., and Barros Neto, J. de P. (2015). "Guidelines for Practice and Evaluation of Sustainable Construction Sites : a Lean , Green and Wellbeing Integrated Approach.” Annual Conference of the IGLC, Perth, Australia, 773-782.

Yin, R. K. (2001). Estudo de caso: planejamento e métodos. Bookman, Porto Alegre.

Yin, R. K. (2011). Qualitative Research From Start To Finish. The Guilford Press, New York.

Yin, R. K. (2013). Case study research: design and methods. SAGE Publications, SAGE Publications, Inc, London. 